\title{
ANALISIS SIKAP KONSUMEN TERHADAP PRODUK OLAHAN SINGKONG
}

\author{
Consumer Attitude Analysis of Cassava Processed of Product Attributes \\ Pradiptya Ayu Harsita dan Amam \\ Fakultas Pertanian, Universitas Jember, Indonesia \\ Jl. Kalimantan No. 37 Jember 68121 \\ pradiptya@unej.ac.id
}

Diterima 31 Maret 2018, disetujui 26 Mei 2019

\begin{abstract}
ABSTRAK
Kandungan karbohidrat singkong yaitu 38 gram per 100 gram singkong atau setara dengan $12 \%$, sehingga singkong cocok dijadikan makanan pengganti beras. Penelitian ini dilakukan di Kabupaten Jombang pada bulan Oktober - November 2017. Sampel untuk penelitian ini adalah siswa Pondok Pesantren Al-Mardliyah Tambakberas. Tujuan penelitian ini untuk menganalisis sikap konsumsi terhadap produk olahan singkong. Atribut yang digunakan dalam penelitian adalah: rasa, warna, bau, dan tekstur. Produk yang digunakan sebagai objek penelitian adalah: singkong rebus, singkong goreng, singkong bakar, keripik singkong, tape, slondok, dan gethuk. Penentuan sampel menggunakan teknik total sampling, yaitu 100 responden. Analisis data menggunakan analisis Fishbein dan analisis deskriptif pada model multi-atribut yang mencakup skor kepercayaan (bi) dan skor evaluasi (ei). Hasil penelitian menyebutkan bahwa secara keseluruhan, hasil dari sikap konsumen terhadap produk olahan singkong adalah positif berdasarkan hasil analisis Fishbein. Keripik singkong merupakan produk olahan singkong dengan nilai atribut paling tinggi dan gethuk merupakan produk olahan singkong dengan nilai atrbut paling rendah. Kesimpulan penelitian ini yaitu produk-produk olahan singkong mempunyai potensi sebagai bahan makanan pengganti nasi.
\end{abstract}

Kata kunci: atribut, konsumen, sikap, dan singkong.

\begin{abstract}
Carbohydrate content of cassava is 38 grams per 100 grams of cassava, equivalent to $12 \%$, so cassava is suitable as a substitute for rice. This research was conducted in Jombang Regency from October to November 2017. The samples for this study were students of Tambakberas Al-Mardliyah Islamic Boarding School. The purpose of this study was to analyze the attitude of consumption of cassava processed products. The attributes used in the study are taste, color, smell, and texture. The products used as research objects are boiled cassava, fried cassava, grilled cassava, cassava chips, tape, slondok, and gethuk. Determination of the sample using total sampling technique with 100 respondents. Data analysis used Fishbein's analysis and descriptive analysis on multi-attribute models which included a trust score (bi) and evaluation score (ei). The results of the study state that overall, the results of consumer attitudes towards cassava processed products was positive based on the results of Fishbein's analysis. Cassava chips it processed cassava products with the highest attribute value and gethuk it a cassava processed product with the lowest attribute value. The conclusion of this study it that cassava processed products have the potential as a substitute for rice.
\end{abstract}

Keywords: attributes, consumers, attitudes, and cassava. 


\section{PENDAHULUAN}

\section{Latar Belakang}

Singkong merupakan bahan pangan alternatif sebagai pengganti beras. Singkong dipilih sebagai bahan pangan alternatif karena produksi singkong di Indonesia melimpah yaitu mencapai 21 juta ton (BPS, 2015). Singkong juga mampu beradaptasi pada wilayah marginal dengan tingkat curah hujan yang rendah, sehingga bisa ditanam di hampir seluruh wilayah di Indonesia.

Karbohidrat singkong yang tinggi $(63,6$ gram) dengan kandungan lemak yang rendah (0,3 gram) mampu menstimulasi perubahan kadar glukosa dalam darah (Mutiyani et al., 2014). Hal tersebut menunjukkan bahwa singkong berpotensi untuk meningkatkan indeks ketahanan pangan di Indonesia karena jumlah produksinya yang tinggi dan sehat untuk dikonsumsi. Rencana Strategis Kementerian Pertanian 2015-2019 menyebutkan bahwa seandainya kondisi perdagangan komoditas tanaman pangan Indonesia dalam posisi defisit atau net importer, maka komoditas pangan penyumbang impor terbesar adalah gandum, kedelai, jagung, dan beras, sedangkan komoditas penyumbang ekspor terbesar adalah singkong.

Diversifikasi pangan untuk merubah pola konsumsi masyarakat harus disertai dengan teknologi pengolahan pangan. Singkong dapat diolah menjadi berbagai macam produk olahan diantaranya: singkong rebus, singkong goreng, singkong bakar, tape, kolak, gethuk, keripik singkong, dan lain sebagainya. Proses pengolahan singkong yang beranekaragam berdampak pada perubahan sifat fisik, kimiawi, dan organoleptiknya, sehingga dapat mempengaruhi minat dan sikap konsumen.

Teori sikap dikembangkan oleh Martin Fishbein dan Ajzen (Amam et al., 2016). Model tersebut membicarakan mengenai sikap seseorang terhadap suatu obyek seperti produk, dimana produk tersebut mempunyai banyak atribut yang dimiliki. Model ini disebut juga sebagai model sikap multi- atribut. Biasanya seorang konsumen di dalam membeli suatu produk atau jasa, pertamatama konsumen akan mencari informasi mengenai produk atau jasa tersebut dan kemudian akan membentuk keyakinan dalam dirinya berdasarkan atribut-atribut tersebut (Amam et al., 2016).

Berdasarkan uraian di atas, peneliti berusaha untuk mengkaji sikap konsumen terhadap keanekaragaman produk olahan singkong. Sikap tersebut diperoleh dari kepercayaan konsumen dan hasil evaluasi konsumen terhadap produk olahan singkong tersebut.

\section{Tujuan Penelitian}

Penelitian bertujuan untuk menganalisis sikap konsumen terhadap atribut produk olahan singkong dan merumuskan perbedaan sikap konsumen terhadap atribut berbagai produk olahan singkong.

\section{Manfaat Penelitian}

Hasil penelitian diharapkan bermanfaat untuk: 1) mengkaji sikap konsumen terhadap atribut berbagai produk olahan singkong, sehingga bisa dilakukan pengembangan produk olahan yang berdaya saing, 2) menentukan perbedaan sikap terhadap atribut, sehingga bisa dijadikan bahan evaluasi untuk meningkatkan kekuatan atribut.

\section{MATERI DAN METODE PENELITIAN}

\section{Lokasi dan Waktu Penelitian}

Penelitian dilakukan di Pondok

Pesantren Al-Mardliyah Tambakberas

Kabupaten Jombang yang dipilih secara purposive sampling dengan pertimbangan bahwa di lokasi tersebut telah dilaksanakan proses adaptasi rekayasa budaya konsumsi singkong sebagai pengganti makanan pokok untuk ketahanan pangan. Pelaksanaan penelitian dilakukan pada bulan Oktober November 2017. 


\section{Metode Penelitian}

Penelitian menggunakan pendekatan diskriptif kualitatif, yaitu dengan pendekatan multi-atribut model dan norma subyektif model. Multi-atribut model digunakan untuk memprediksi sikap masyarakat terhadap pangan berbahan dasar singkong yang terdiri dari skor kepercayaan dan skor evaluasi (Amam et al., 2016). Atribut yang digunakan dalam penelitian yaitu: rasa, warna, bau, dan tekstur. Produk yang dijadikan obyek penelitian ialah: singkong rebus, singkong goreng, singkong bakar, keripik singkong, tape, slondok, dan gethuk.

\section{Metode Penentuan Sampel}

Sampel ditentukan dengan teknik total sampling, yaitu pemilihan sampel secara keseluruhan untuk mendapatkan data sesuai tujuan penelitian. Sampel yang digunakan yaitu 100 responden sesuai dengan proses adaptasi rekayasa budaya konsumsi singkong.

\section{Metode Pengumpulan Data}

Responden diminta untuk menanggapi masing-masing atribut produk olahan singkong untuk memperoleh skor kepercayaan konsumen (Amam et al., 2016). Skor kepercayaan tersebut terdiri dari lima kategori, yaitu: sangat percaya (skor +2 ), percaya (skor +1 ), netral (skor 0 ), tidak percaya (skor -1), dan sangat tidak percaya (skor -2).

Responden diminta untuk mengevaluasi masing-masing atribut produk olahan singkong untuk memperoleh skor evaluasi konsumen (Amam et al., 2016). Skor evaluasi tersebut terdiri dari lima kategori, yaitu: sangat percaya (skor +2$)$, percaya (skor +1$)$, netral (skor 0), tidak percaya (skor -1), dan sangat tidak percaya (skor -2).

\section{Penilaian Konsumen}

Pembentukan interval kelas menurut Amam et al. (2016) ditentukan secara matematis sebagai berikut:

$=\frac{(\text { skor tertinggi }- \text { skor terendah })}{\text { jumlah kelas }}$
$=((+2)-(-2)) / 5$

$=4 / 5$

$=0,8$

Berdasarkan perhitungan interval kelas, maka didapatkan skor penilaian sebagai berikut:

skor sangat rendah : $-2,00 \mathrm{~s} / \mathrm{d}-1,20$

skor rendah $\quad:-1,19 \mathrm{~s} / \mathrm{d}-0,40$

skor sedang $\quad:-0,39 \mathrm{~s} / \mathrm{d} \quad 0,40$

skor tinggi $\quad: 0,41 \mathrm{~s} / \mathrm{d} \quad 1,20$

skor sangat tinggi : $1,21 \mathrm{~s} / \mathrm{d} \quad 2,00$

\section{Teknik Analisis Data}

Sikap total konsumen terhadap produk singkong ditentukan sebagai berikut: (a) jika Ao $<0$, maka nilai sikap total konsumen negatif, (b) jika Ao $>0$ maka nilai sikap total konsumen positif, dan (c) jika Ao $=0$ maka nilai sikap total konsumen tetap. Analisis Fishbein secara matematis ialah sebagai berikut:

$$
\mathrm{A} o=\sum_{i=1}^{n} b i e i
$$

Keterangan:

Ao $=$ sikap terhadap obyek,

bi = kekuatan kepercayaan bahwa obyek memiliki atribut $i$,

ei = evaluasi mengenai atribut $\mathrm{i}$, dan

$\mathrm{n} \quad=$ jumlah atribut yang menonjol

(Amam et al., 2016)

\section{HASIL DAN PEMBAHASAN}

\section{Gambaran Umum Lokasi Penelitian}

Pondok Pesantren Al-Mardliyah Bahrul

Ulum Tambakberas Kabupaten Jombang terletak di Dusun Tambakberas, Desa Tambakrejo, Kecamatan Jombang, Kabupaten Jombang, Provinsi Jawa Timur, tepatnya \pm 3 $\mathrm{km}$ sebelah utara Kota Jombang. Pondok Pesantren di Tambakberas memiliki kondisi sosio-kultur religius agraris.

Pondok Pesantren Al-Mardliyah Bahrul Ulum Tambakberas Kabupaten Jombang merupakan salah satu pondok tertua dan terbesar di Jawa Timur yang hingga sekarang masih bertahan dengan budaya tradisional 
yang berlangsung secara turun-menurun. Sifatnya yang kultural, sederhana, mandiri serta dekat dengan masyarakat membuat Pondok Pesantren Bahrul Ulum terus melakukan pengembangan dan perubahan seiring dengan dinamika perkembangan dan tuntutan global, dengan tetap mempertahankan nilai-nilai luhur kepesantrenan dan prinsip-prinsip aqidah ahli sunnah wal-jama'ah. Secara struktural Pondok Pesantren Al-Mardliyah Bahrul Ulum berada di bawah naungan Yayasan Pondok Pesantren Bahrul Ulum.

\section{Umur Konsumen}

Data penelitian menunjukkan bahwa umur konsumen olahan singkong dibedakan menjadi empat kategori, yaitu: a) umur 16-17 tahun, b) umur 18-19 tahun, c) umur 20-21 tahun, dan d) umur 22-23 tahun.

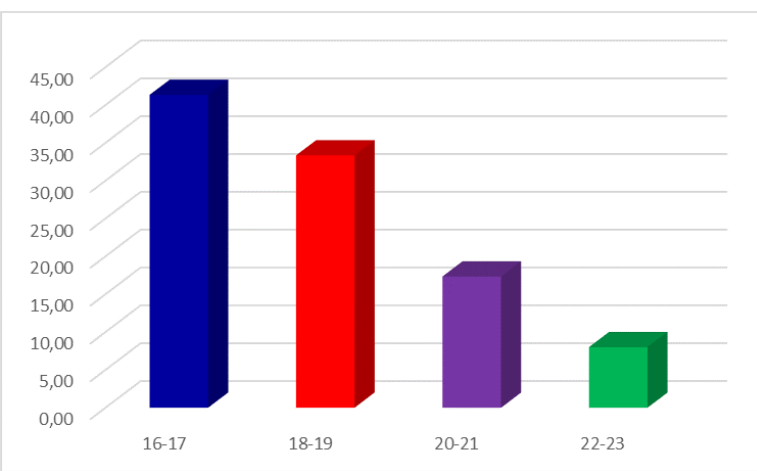

Gambar 1. Umur Konsumen

Gambar 1 menunjukkan bahwa konsumen olahan singkong pada umur 16-17 tahun sebanyak 31 orang, umur 18-19 tahun sebanyak 25 orang, umur 20-21 tahun sebanyak 13 orang, dan umur 22-23 sebanyak 6 orang. Rahardjo dan Mulyanto (2018) menyebutkan bahwa responden perempuan dengan usia 16-26 tahun merupakan responden dengan tingkat konsumsi keripik singkong terbanyak sebesar $21 \%$. Responden tersebut merupakan kalangan remaja perempuan karena memang sebagian perempuan lebih suka mengkonsumsi makanan ringan dari pada lak-laki (Rahardjo dan Mulyanto, 2018).

\section{Faktor yang sering Menjadi Pertimbangan Konsumen}

Data penelitian menunjukkan bahwa faktor yang sering menjadi pertimbangan konsumen dalam mengkonsumsi produk olahan singkong antara lain: a) manfaat, b) rasa, c) gaya hidup, d) harga, dan e) keadaan.

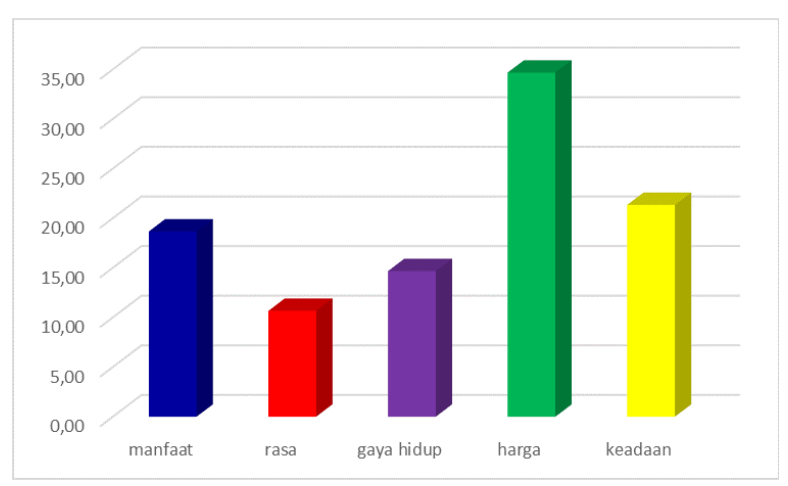

Gambar 2. Faktor yang Menjadi Pertimbangan Konsumen

Gambar 2 menunjukkan bahwa harga merupakan faktor yang menjadi pertimbangan konsumen singkong tertinggi. Harga singkong mentah di lokasi penelitian sebesar Rp 3.500 per kilogram, sedangkan harga beras sebesar Rp 11.000 per kilogram. Murahnya harga bahan baku singkong berdampak pada terjangkaunya harga produk olahan singkong. Oktrisa et al. (2015) menjelaskan bahwa mayoritas konsumen singkong memberikan nilai 2 yang artinya biasa saja terhadap indikator harga, kemudahan memperoleh, citra, dan tampilan produk jajanan singkong. Hal tersebut menunjukkan bahwa jajanan singkong masih dianggap biasa, dinilai baik namun tidak dianggap spesial.

Rasa merupakan faktor yang menjadi pertimbangan konsumen singkong terendah. Indariawati et al. (2011) menyebutkan bahwa kecenderungan konsumen lebih memilih singkong dengan rasa singkong asli (54\%) dari pada singkong yang berbumbu (46\%).

\section{Tingkat Kepentingan Atribut}

Data penelitian menunjukkan bahwa tingkat kepentingan atribut menurut konsumen terdiri dari: a) atribut rasa, b) atribut harga, c) atribut warna, d) atribut 
bau, dan e) atribut tekstur. Secara diskripsi tingkat kepentingan atribut tersebut digambarkan sebagai berikut:

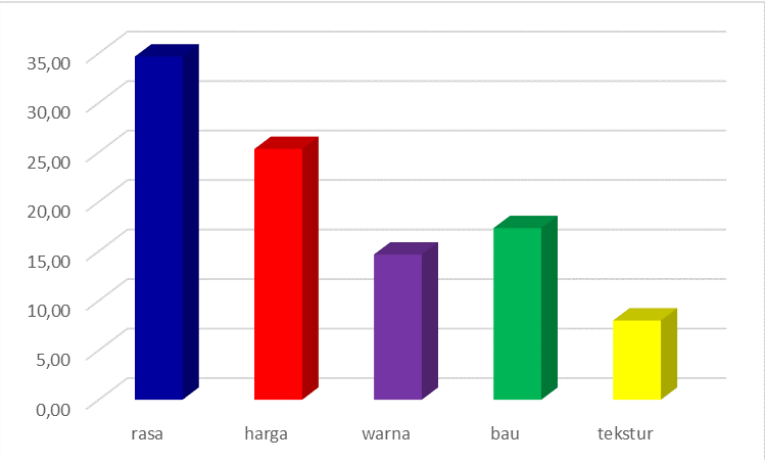

Data gambar 3 menunjukkan bahwa rasa merupakan tingkat kepentingan atribut paling tinggi jika dibandingkan dengan atribut yang lain. Hal tersebut menunjukkan bahwa karena rasa singkong merupakan faktor yang menjadi pertimbangan konsumen terendah, sehingga rasa yang enak merupakan atribut yang paling penting. Hal senada juga dijelaskan Oktrisa et al. (2015) yang menyebutkan bahwa jajanan singkong dianggap biasa, dinilai baik namun tidak spesial. Salah satu strategi untuk pengembangan usaha berbasis singkong dengan cara konsep produk (product concept) dan mutu produksi (Indariawati et al., 2011).

Berbagai upaya untuk meningkatkan rasa dari produk singkong diantaranya yaitu dikonsumsi secara langung, pengolahan setengah jadi, pengolahan fermentasi, dan pengolahan tapioka (Darwis et al., 2010). Salah satu jenis olahan singkong yang digemari masyarakat yaitu keripik singkong karena rasarnya enak, gurih, dan harganya

Tabel 1. Skor Kepercayaan Konsumen
Gambar 3. Tingkat Kepentingan Atribut

juga terjangkau (Aini et al., 2014). Rasa asin merupakan rasa yang paling disukai konsumen keripik singkong (Indariawati et al., 2011).

\section{Analisis Multi-atribut Model Menentukan Skor Kepercayaan Konsumen (bi)}

Tingkat kepercayaan konsumen terhadap atribut produk olahan singkong sebelum mengkonsumi. Atribut tersebut terdiri dari atribut rasa, warna, bau, dan tekstur. Skor kepercayaan konsumen terhadap atribut olahan singkong ditunjukkan pada Tabel 1.

Data pada Tabel 1 menunjukkan bahwa penilaian atribut menurut konsumen yaitu atribut rasa tertinggi pada produk keripik singkong yaitu sebesar 0,92 sesuai dengan kekuatan atribut pada Gambar 4. Aini et al. (2014) menyebutkan bahwa salah satu jenis olahan singkong yang digemari masyarakat yaitu keripik singkong karena rasarnya enak, gurih, dan harganya juga terjangkau. Keripik singkong dengan rasa asin merupakan rasa yang paling banyak digemari konsumen (Indariawati et al., 2011).

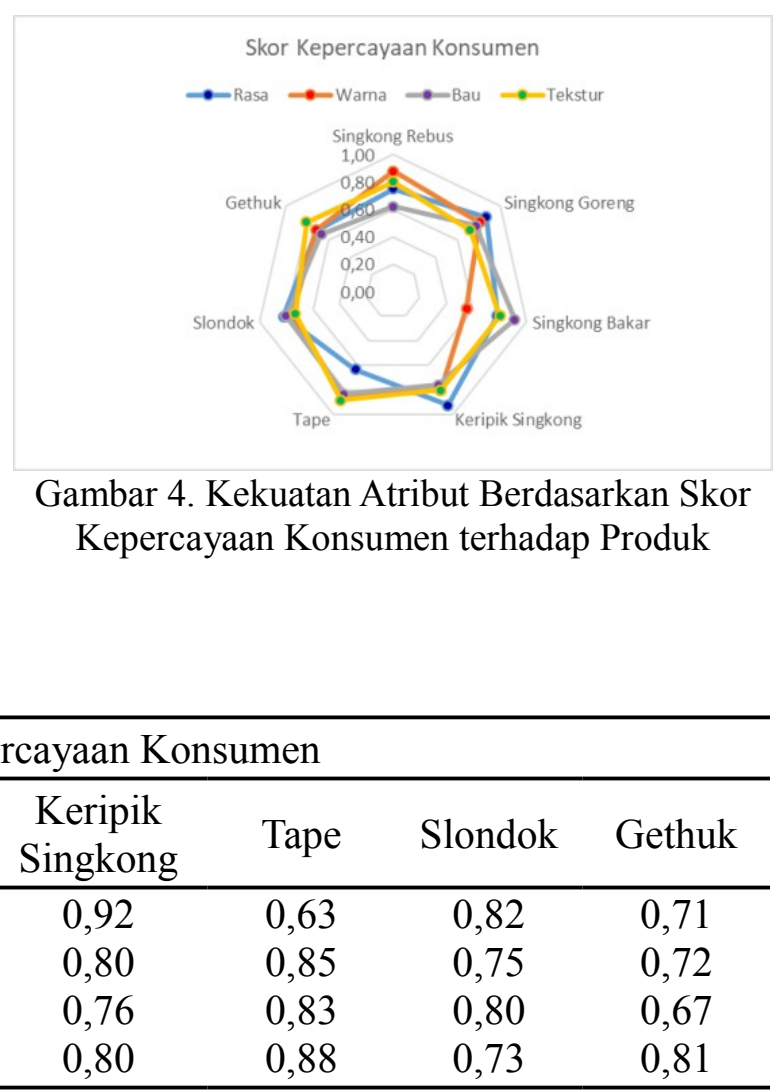

Sumber: Data primer (diolah, 2017)

Skor Kepercayaan Konsumen

\begin{tabular}{lccccccc}
\cline { 2 - 7 } Atribut & $\begin{array}{c}\text { Singkong } \\
\text { Rebus }\end{array}$ & $\begin{array}{c}\text { Singkong } \\
\text { Goreng }\end{array}$ & $\begin{array}{c}\text { Singkong } \\
\text { Bakar }\end{array}$ & $\begin{array}{c}\text { Keripik } \\
\text { Singkong }\end{array}$ & Tape & Slondok & Gethuk \\
\hline rasa & 0,75 & 0,87 & 0,78 & 0,92 & 0,63 & 0,82 & 0,71 \\
warna & 0,88 & 0,81 & 0,55 & 0,80 & 0,85 & 0,75 & 0,72 \\
bau & 0,62 & 0,77 & 0,91 & 0,76 & 0,83 & 0,80 & 0,67 \\
tekstur & 0,80 & 0,72 & 0,80 & 0,80 & 0,88 & 0,73 & 0,81 \\
\hline
\end{tabular}


Kekuatan atribut pada Gambar 4 menunjukkan bahwa atribut keripik singkong mempunyai kekuatan yang dominan. Tingkat kepercayaan konsumen dapat mempengaruhi minat beli konsumen. Minat beli merupakan sesuatu yang berhubungan dengan rencana konsumen untuk membeli produk tertentu, serta berapa banyak unit produk yang dibutuhkan pada periode tertentu (Raharjo dan Mulyanto, 2018).

\section{Menentukan Skor Evaluasi Konsumen (ei)}

Skor evaluasi konsumen terhadap atribut diperoleh setelah konsumen mengkonsumsi produk olahan singkong. Skor evaluasi digunakan sebagai pembanding dari skor kepercayaan.

Atribut tersebut terdiri dari atribut rasa, warna, bau, dan tekstur. Skor evaluasi konsumen terhadap atribut olahan singkong ditunjukkan pada Tabel 2.

Data pada Tabel 2 menunjukkan bahwa penilaian atribut menurut konsumen yaitu atribut rasa tertinggi pada produk keripik singkong yaitu sebesar 0,94 sesuai dengan kekuatan atribut pada Gambar 5. Salah satu jenis olahan singkong yang digemari masyarakat yaitu keripik singkong karena rasarnya enak, gurih, dan harganya juga terjangkau. Rasa adalah salah satu faktor yang cukup mempengaruhi keputusan pembelian konsumen terhadap keripik singkong (Aini et al., 2014).

Kekuatan atribut pada Gambar 5 menunjukkan bahwa atribut keripik singkong mempunyai kekuatan yang dominan. Tingkat kepercayaan konsumen dapat mempengaruhi minat beli konsumen. Raharjo dan Mulyanto

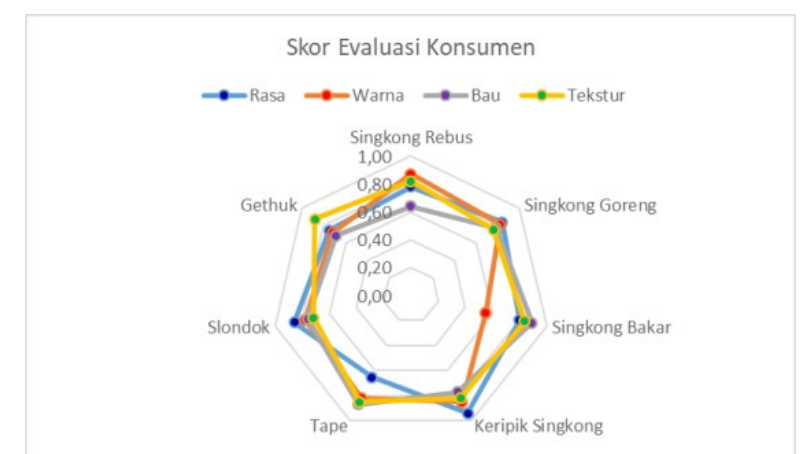

Gambar 5. Kekuatan Atribut Berdasarkan Skor Evaluasi Konsumen terhadap Produk

(2018) menyebutkan bahwa minat beli merupakan sesuatu yang berhubungan dengan rencana konsumen untuk membeli produk tertentu, serta berapa banyak unit produk yang dibutuhkan pada periode tertentu.

\section{Menentukan Sikap Konsumen (Ao)}

Berdasarkan hasil yang diperoleh dari skor kepercayaan dan skor evaluasi konsumen terhadap atribut produk olahan singkong, maka untuk mengukur sikap konsumen terhadap atribut produk olahan singkong yaitu dengan cara mengkalikan skor kepercayaan (sebelum mengkonsumsi) dengan skor evaluasi (setelah mengkonsumsi) melalui pendekatan Fishbein. Hasil analisis tersebut ditunjukkan pada Tabel 3.

Data pada Tabel 3 menunjukkan bahwa nilai sikap konsumen terhadap atribut produk olahan singkong mempunyai nilai positif. Artinya bahwa tingkat kepercayaan dan evaluasi konsumen bernilai positif, baik sebelum mengkonsumsi produk olahan singkong maupun setelah mengkonsumsi produk olahan singkong. Sikap konsumen

Tabel 2. Skor Evaluasi Konsumen

\begin{tabular}{lccccccc}
\hline \multirow{2}{*}{ Atribut } & \multicolumn{7}{c}{ Skor Evaluasi Konsumen } \\
\cline { 2 - 8 } & $\begin{array}{c}\text { Singkong } \\
\text { Rebus }\end{array}$ & $\begin{array}{c}\text { Singkong } \\
\text { Goreng }\end{array}$ & $\begin{array}{c}\text { Singkong } \\
\text { Bakar }\end{array}$ & $\begin{array}{c}\text { Keripik } \\
\text { Singkong }\end{array}$ & Tape & Slondok & Gethuk \\
\hline rasa & 0,78 & 0,84 & 0,80 & 0,94 & 0,65 & 0,86 & 0,75 \\
warna & 0,87 & 0,82 & 0,55 & 0,85 & 0,82 & 0,78 & 0,72 \\
bau & 0,64 & 0,78 & 0,89 & 0,77 & 0,87 & 0,76 & 0,69 \\
tekstur & 0,82 & 0,76 & 0,84 & 0,82 & 0,85 & 0,72 & 0,88 \\
\hline
\end{tabular}

Sumber: Data primer (diolah, 2017) 
Tabel 3. Analsis Sikap Konsumen

\begin{tabular}{lccccccc}
\hline \multirow{2}{*}{ Atribut } & \multicolumn{7}{c}{ Sikap Konsumen Singkong } \\
\cline { 2 - 8 } & $\begin{array}{c}\text { Singkong } \\
\text { Rebus }\end{array}$ & $\begin{array}{c}\text { Singkong } \\
\text { Goreng }\end{array}$ & $\begin{array}{c}\text { Singkong } \\
\text { Bakar }\end{array}$ & $\begin{array}{c}\text { Keripik } \\
\text { Singkong }\end{array}$ & Tape & Slondok & Gethuk \\
\hline rasa & 0,59 & 0,73 & 0,62 & 0,86 & 0,41 & 0,71 & 0,53 \\
warna & 0,77 & 0,66 & 0,30 & 0,68 & 0,70 & 0,59 & 0,52 \\
bau & 0,40 & 0,60 & 0,81 & 0,59 & 0,72 & 0,61 & 0,46 \\
tekstur & 0,66 & 0,55 & 0,67 & 0,66 & 0,75 & 0,53 & 0,71 \\
\hline Sikap & 2,40 & 2,54 & 2,41 & 2,79 & 2,58 & 2,42 & 2,23 \\
\hline
\end{tabular}

Sumber: Data primer (diolah, 2017)

tertinggi terdapat pada produk olahan keripik singkong (2,79). Sarwoko dan Churiyah (2007) menyebutkan bahwa atribut produk memiliki pengaruh yang sangat besar terhadap keputusan pembelian konsumen. Atribut produk olahan singkong dipaparkan pada Gambar 6.

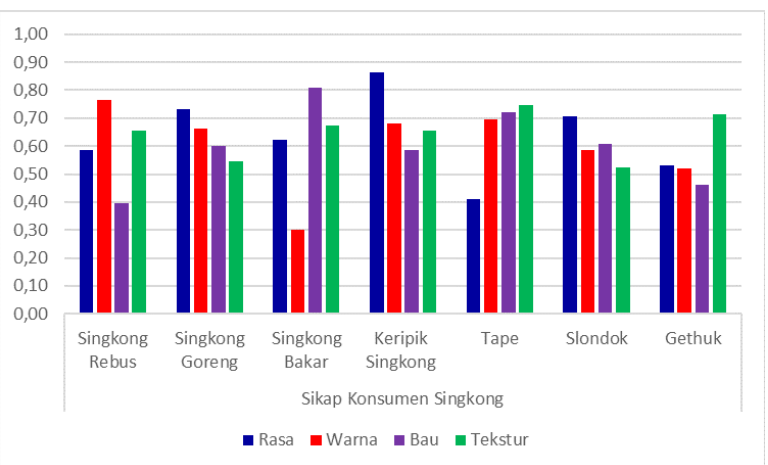

Gambar 6. Analisis Multi-atribut Model

Sikap konsumen terhadap atribut-atribut berbagai produk olahan singkong bernilai positif. Artinya, ada harapan bahwa suatu saat singkong dapat digunakan sebagai bahan pangan alternatif pengganti beras. Agustina dan Widayati (2012) mengungkapkan bahwa masyarakat dituntut untuk bisa mencari pengganti bahan pokok beras sebagai bahan konsumsi sehari-hari yang salah satunya bersumber dari singkong. Hal tersebut sebagai dampak dari mahalnya harga beras lokal karena musim panen yang tidak menentu dan serangan hama, sedangkan subsidi beras oleh Bulog hanya mampu diserap sebesar 7-10\% dari produksi nasional.

Prayogi (2017) menyebutkan bahwa singkong layak dijadikan makanan pokok pengganti beras mengingat tingginya kadar nutrisi di dalam singkong. Kadar HCN dalam singkong dapat mempengaruhi rasa singkong, sehingga bisa digunakan sebagai beras analog. Ismail et al. (2014) menjelaskan bahwa beras analog merupakan sebutan lain dari beras tiruan (artificial rice) yang dibuat dari bahan non-padi dengan kandungan karbohidrat yang mendekati atau melebihi dengan bentuk menyerupai beras dan dapat berasal dari tepung lokal ataupun padi. Salah satu upaya untuk meningkatkan nilai nutrisi dari beras analog dari singkong ialah penambahan protein tepung udang (Jannah et al., 2015).

Produk-produk berbahan dasar singkong dapat mendukung program pemerintah dalam melestarikan swasembada karbohidrat yang perlu didukung dengan memanfaatkan jenis komoditas selain beras (Simanjuntak, 2006). Pemanfaatan jenis komoditas selain beras sangat ditentukan oleh minat konsumen. Kekuatan atribut konsumen terhadap produk olahan singkong dapat dilihat pada Gambar 7.

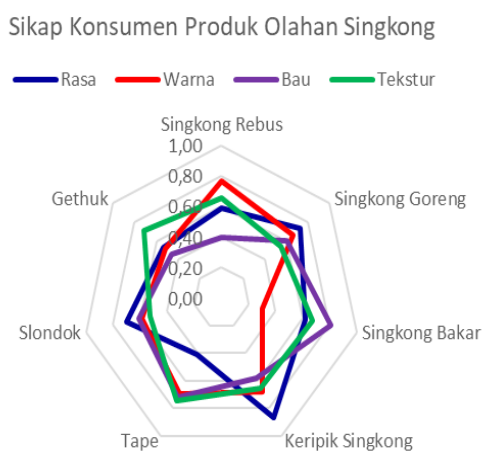

Gambar 7. Kekuatan Atribut Konsumen 
Kekuatan semua atribut menunjukkan nilai positif, sehingga ada potensi bahwa singkong sudah diterima masyarakat secara luas. Pemanfaatan singkong sebagai makanan pokok telah lama dilakukan, hanya saja semakin lama kecenderungan konsumsi singkong masyarakat semakin berkurang (Khairani dan Dalapati, 2011). Salah satu upaya untuk meningkatkan kembali daya tarik singkong ialah dengan diversifikasi pangan. Undang-undang Pangan Nomor 18 Tahun 2012 menyebutkan bahwa penganekaragaman (diversifikasi) pangan adalah upaya peningkatan ketersediaan dan konsumsi pangan yang beragam, bergizi, dan berbasis pada potensi sumber daya lokal.

Penganekaragaman pangan juga merupakan salah satu upaya menyediakan dan mengkonsumsi pangan dengan menu yang beraneka ragam dan bervariasi (Khuzaimah, 2016). Hal tersebut karena masyarakat dituntut untuk bisa mencari pengganti bahan pokok beras sebagai bahan konsumsi seharihari yang salah satunya bersumber dari singkong (Agustina dan Widayati, 2012).

Beberapa produk olahan singkong yang dijadikan obyek penelitian yaitu singkong rebus, singkong goreng, singkong bakar, keripik singkong, tape, slondok, dan gethuk mempunyai daya tarik bagi konsumen berdasarkan sikap konsumen sendiri. Nilai sikap tersebut ditunjukkan pada Gambar 8 .

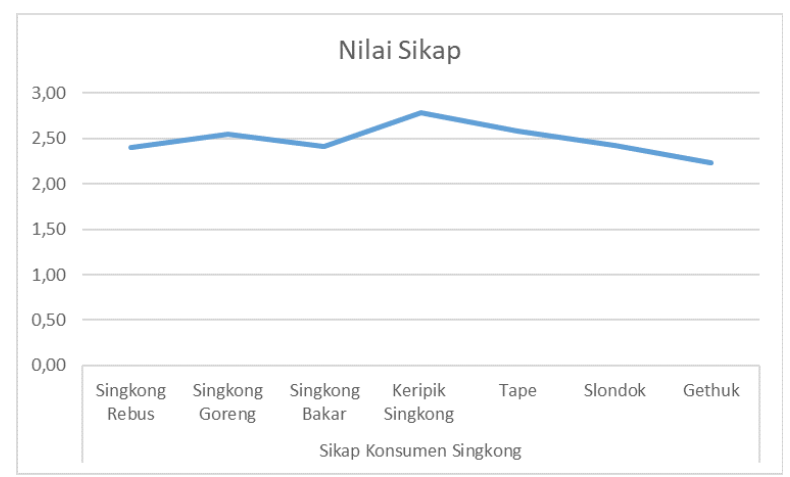

Gambar 8. Kekuatan Sikap yang Mempengaruhi Sikap Konsumen

Sikap konsumen yang paling menonjol pada berbagai produk olahan singkong ialah keripik singkong. Berdasarkan informasi yang diperoleh dari konsumen di lokasi penelitian, konsumen menjelaskan bahwa keripik singkong ialah salah satu produk olahan singkong yang enak, praktis, dan cocok dijadikan makanan ringan di sela-sela waktu sibuk. Aini et al. (2014) menjelaskan bahwa salah satu jenis olahan singkong yang digemari masyarakat yaitu keripik singkong karena rasarnya enak, gurih, dan harganya juga terjangkau.

Industri pengolahan singkong menjadi potensi bisnis yang menjanjikan mengingat sikap konsumen yang bernilai positif, terutama industri pengolahan keripik singkong. Pendapatan usaha keripik singkong mencapai Rp 3.241.416 per orang per bulan (Henakin dan Taena, 2018). Keuntungan penjualan keripik singkong dalam kemasan mancapai 45\% (Soebiyakto dan Alfiana, 2017).

\section{KESIMPULAN}

Sikap konsumen terhadap berbagai produk olahan singkong bernilai positif. Hal tersebut menunjukkan bahwa singkong bisa dijadikan alternatif sebagai bahan pangan pokok pengganti beras.

Nilai positif paling tinggi berdasarkan sikap konsumen ialah keripik singkong. Keripik singkong dinilai enak, praktis, dan cocok dijadikanan makanan ringan.

\section{DAFTAR PUSTAKA}

Agustina, M. dan Q. Widayati. 2012. Sawut Pengganti Nasi. Prosiding. Seminar Nasional Kewirausahaan dan Inovasi Bisnis II. Jakarta. 20 September 2012. p. 1-4.

Aini, S. N., I. Syafi'i, dan E. Kuntadi. 2014. Perilaku konsumen dalam pembelian keripik singkong rasa asin di Kabupaten Bondowoso. J. Berkala Ilmiah. 1 (1): 1-8.

Amam, Z., Fanani, dan B. A. Nugroho. 2016. Analis sikap konsumen terhadap susu bubuk berkalsium tinggi dengan menggunakan multi-atribut dan norma subyektif model. J. Wacana. 19 (1): 112. 
BPS. 2015. Produksi Ubi Kayu Menurut Provinsi (Ton) 1993-2015. Badan Pusat Statistik. https://www.bps.go.id/ linkTableDinamis/view/id/880 Diakses tanggal 27 Febaruari 2018.

Darwis, P., C. Muslim, dan A. Askin. 2010. Usahatani dan pemasaran ubi kayu serta teknologi pengolahan tapioka di Kabupaten Pati, Provinsi Jawa Timur. Litbang Pertanian. 324-340.

Henakin, F. K. O. dan W. Taena. 2018. Analisi nilai tambah singkong sebagai bahan baku produk keripik di kelompok usaha bersama sehati Desa Batnes Kecamatan Musi. J. Agrimor. 3 (2): 23-26.

Indariawati, P., S. Raharja, dan S. T. Soekarto. 2011. Kajian strategi pengembangan usaha industri keripik singkong Perusahaan PT Inti Sari Rasa di Bekasi. J. Manajemen IKM. 6 (2): 99104.

Ismail, E. W., L. Kurniawati, dan N. Suhartatik. 2014. Formulasi beras analog dari singkong (Manihot utilisima) dengan variasi penambahan ubi jalar (Ipomoea batats L.) (putih, kuning, dan ungu). J. Jitipari. 4 (1): 112-118.

Jannah, M., Tamrin, C. Sugianti, dan Warji. 2015. Pembuatan dan uji karakteristik fisik beras analog berbahan baku tepung singkong yang diperkaya dengan protein udang. J, Teknik Pertanian Lampung. 4 (1): 51-56.

Khairani, C. dan A. Dalapati. 2011. Keragaan teknologi pengolahan ubi kayu sebagai alternatif makanan pokok di Sulawesi Tengah. Balai Pengkajian Teknologi Pertanian Sulawesi Tengah. 620-625.

Khuzaimah, U. 2016. Analisis Kemandirian Ubi Kayu dan Ubi Jalar Mendukung Diversifikasi Pangan Pokok Jawa
Barat. Skripsi. Program Sarjana Institut Pertanian Bogor. Bogor.

Mutiyani, M., Soeatmadji, dan D. Wahono. 2014. Efek diet tinggi karbohidrat dan diet tinggi lemak terhadap kadar glukosa darah dan kepadatan sel beta. Indonesian Journal of Human Nutrition. 1 (2): 106-113.

Oktrisa, T., W. D. Sayekti, dan I. Listiana. 2015. Persepsi, preferensi, dan pola konsumsi makanan jajanan berbasis singkong terhadap remaja: Kasus di SMAN 2 Bandar Lampung dan SMAN 1 Tumijajar Tulang Bawang Barat. JIIA. 3 (2): 219-227.

Prayogi, D. 2017. Pengembangan potensi wisata kuliner Kota Malang berbasis sumber daya lokal. J. Pesona. 2 (1): 113.

Rahardjo, R. M. dan H. Mulyanto. 2018. Kualitas produk, citra merek, dan minat beli konsumen keripik singkong. J. Manajemen Kewirausahaan. 15 (1): 109-120.

Sarwoko, E. dan M. Churiyah. 2007. Pengaruh sikap konsumen terhadap keputusan pembelian minuman merek aqua berkaitan dengan penerapan Program CSR (Corporate Social Responsi-bility). J. Ekonomi Modernisasi. 3 (2): 147-163.

Simanjuntak, D. 2006. Pemanfaatn komoditas non beras dalam diversifikasi pangan sumber kalori. J. Penelitian Bidang Ilmu Pertanian. 4 (1): 45-54.

Soebiyakto, G. dan A. Alfiana. 2017. Iptek bagi masyarakat: kelompok usaha kripik singkong di Kelurahan Pagentan Kecamatan Singosari Kabupaten Malang. JATI EMAS. 1(1) : 1-4. 